\title{
Heat-Stable Carbetocin Could Replace Oxytocin To Prevent Postpartum Haemorrhage Following Vaginal Delivery
}

\begin{abstract}
Bikram Thapa
Intern doctor, Nepalese Army Institute of Health Sciences, Shree Birendra Hospital, Chhauni, Kathmandu, Nepal
\end{abstract}

\section{INTRODUCTION}

Postpartum haemorrhage (PPH) is the most common type of obstetric haemorrhage and accounts for $35 \%$ of all maternal deaths. ${ }^{1}$ World Health Organisation (WHO) defines PPH as: blood loss of $500 \mathrm{~mL}$ or more within 24 hours following vaginal delivery. PPH is the leading cause of maternal mortality in low-income countries, and the primary cause of nearly one quarter of all maternal deaths globally. ${ }^{2}$

Uterine atony is the most common cause of $\mathrm{PPH}$ accounting for more than $80 \%$ of causes. Thus, to prevent $\mathrm{PPH}$, WHO has recommended active management of third stage of labor. All women giving birth should be offered uterotonics during the third stage of labor (as a part of third stage management) for the prevention of $\mathrm{PPH}$; oxytocin (IM/IV, $10 \mathrm{IU}$ ) is recommended as the uterotonic drug of choice. ${ }^{3}$

\section{CONTEXT}

Oxytocin is a heat-sensitive uterotonic drug and has to be stored in 2 to $8^{\circ} \mathrm{C}$ to ensure efficacy. In room temperature oxytocin undergoes heat degradation. In settings where oxytocin is used, attention should be paid to the oxytocin cold chain (i.e. the requirements of a temperature-controlled supply chain). ${ }^{3}$ Facilities for storing and transporting in a cold chain is a matter of challenge in resource limited countries. So, real-world efficacy of oxytocin is unsatisfactory especially in developing countries. ${ }^{3}$ Heat-stable Carbetocin, an oxytocin analogue, can be a solution to overcome this limitation with current standard therapy.

A recent study, CHAMPION (Carbetocin HAeMorrhage PreventION) trial has shown that Heat-stable Carbetocin is "non-inferior" to oxytocin for prevention of PPH following vaginal delivery.

\section{The CHAMPION Trial ${ }^{4}$}

An international, randomised, double-blind, noninferior clinical trial (the CHAMPION trial) was carried out at 23 hospitals in 10 countries (Argentina, Egypt, India, Kenya, Nigeria, Singapore, South Africa, Thailand, Uganda and the United Kingdom). CHAMPION trial is the largest

Correspondence: Bikram Thapa, Nepalese Army Institute of Health Sciences, Shree Birendra Hospital, Chhauni, Kathmandu, Nepal. Email: bikramt23@gamil.com

DOI: $10.3126 / \mathrm{mjsbh.v18i1.21063}$

Submitted on: 2018-011-13

Accepted on: 2018-12-25

This work is licensed under creative common license:

http://creativecommons.org/licenses/by-nc-nd/4.0/ C MJSBH 2018 
Table 1. Outcome of CHAMPION trial

\begin{tabular}{|c|r|r|}
\hline \multicolumn{1}{|c|}{ Blood loss } & H-S Carbetocin & Oxytocin \\
\hline At least $500 \mathrm{~mL}$ & $14.5 \%$ & $14.4 \%$ \\
\hline At least $1000 \mathrm{~mL}$ & $1.51 \%$ & $1.45 \%$ \\
\hline
\end{tabular}

clinical trial carried out in prevention of postpartum haemorrhage that included 29,645 women from 2013 to $31^{\text {st }}$ May 2018. This trial was conducted by the WHO Department of Reproductive Health and Research including the UNDP-UNFPA-UNICEFWHO-World Bank Special Program of Research, Development and Research Training in Human Reproduction (HRP), using Ferring's heat-stable carbetocin, and funded by MSD for Mothers. Women who had singleton pregnancy, expected to have vaginal delivery and cervical dilatation $\leq 6 \mathrm{~cm}$ were included in the trial.

These women, just following delivery, were given either of injection heat-stable carbetocin $(100 \mu \mathrm{g})$ intramuscularly or injection oxytocin $10 \mathrm{U}$ intramuscularly. Heat-stable carbetocin (although does not require refrigeration) was also stored in 2 to $8^{\circ} \mathrm{C}$ for double blinding. Rest of third stage of labor was managed as per WHO guidelines.

At the end of study, the primary outcome was: $14.5 \%$ of those women who received carbetocin and $14.4 \%$ who received oxytocin had blood loss of at least $500 \mathrm{~mL}$ (or require use of additional uterotonic drug). The secondary outcome of the study was: $1.51 \%$ of women in carbetocin and $1.45 \%$ of those in oxytocin had at least $1000 \mathrm{~mL}$ of blood loss (Table 1).

The result of study was: heat stable carbetocin is noninferior to oxytocin to prevent postpartum haemorrhage.

The major side effect of both heat-stable carbetocin and oxytocin observed in the study were chest pain, flushing, abdominal pain and vomiting. These
Table 2. Comparison of side effects

\begin{tabular}{|c|c|c|}
\hline Side effects & $\begin{array}{c}\mathrm{H}-\mathrm{S} \\
\text { Carbetocin }\end{array}$ & Oxytocin \\
\hline Chest pain & $13(0.09 \%)$ & $6(0.04 \%)$ \\
\hline Flushing & $5(0.03 \%)$ & $4(0.03 \%)$ \\
\hline $\begin{array}{l}\text { Abdominal } \\
\text { pain }\end{array}$ & $63(0.43 \%)$ & $56(0.38 \%)$ \\
\hline Vomiting & $33(0.22 \%)$ & $27(0.18 \%)$ \\
\hline
\end{tabular}

effects were observed in less than $0.5 \%$ of either group of study population (Table 2).

\section{DISCUSSION}

Postpartum haemorrhage is one of major cause of maternal mortality. The use of oxytocin, which is current standard uterotonic drug for prevention of $\mathrm{PPH}$, is limited by its heat degradation property in rural areas of most developing countries. Cold chain required for storage and transportation of oxytocin thus is the barrier for either availability or maximum efficacy of the drug in these countries, failing to prevent mortality (or severe morbidity) due to PPH. Studies in low- and lower-middle income countries have revealed degradation and loss of efficacy in oxytocin ampoules, which could be due to inadequate storage and distribution conditions. ${ }^{5}$ Heat stable carbetocin can be a major breakthrough for this problem. Heat stable carbetocin is stable for at least three years at $30^{\circ} \mathrm{C}$ and for six months at $40^{\circ} \mathrm{C}$ thereby eliminating the need of cold chain for storage and transportation. ${ }^{6}$

\section{CONCLUSIONS}

The cost and availability of heat stable carbetocin should not be an issue in developing countries as the drug was studied targeting the developing countries. WHO will now ask their Guideline Development Group to consider Heat stable carbetocin in recommendation as drug to prevent $\mathrm{PPH}$, and following positive response, will work 
with studying parties to make this drug available at affordable cost to the countries with high burden of maternal death from PPH. ${ }^{7}$ Heat stable carbetocin, which is non-inferior to and has similar safety profile to oxytocin, can be a lifesaving uterotonic drug to prevent deaths from postpartum haemorrhage.
With further study on heat-stable carbetocin, we can hope to see this drug in the new update in WHO recommendation for prevention of postpartum haemorrhage; that undoubtedly would be a very remarkable change, especially for resource limited countries like ours.

To cite this article: Thapa B. Heat-stable carbetocin could replace oxytocin to prevent postpartum haemorrhage following vaginal delivery. MJSBH. 2019;18(1):75-7.

Conflict of Interest: None declared

\section{REFERENCES}

1. Countdown to 2015: Maternal, Newborn and Child Survival. WHO and UNICEF, 2012.

2. Say L, Chou D, Gemmill A, Tuncalp O, Moller AB, Daniels J, et al. Global causes of maternal death: WHO systematic analysis. LGH. 2014;2(6):323-33.

DOI: 10.1016/S2214-109X(14)70227-X

3. World Health Organisation. WHO recommendations for the prevention and treatment of postpartum haemorrhage. WHO 2012.

4. Widmer M, Piaggio G, Nguyen TMH, Osoti A, Owa OO, Misra S, et al. Heat-Stable Carbetocin Versus Oxytocin to Prevent Haemorrhage after Vaginal Birth. NEJM. 2018;379:743-52

DOI: 10.1056/NEJMoa1805489

5. Torloni MR, Gomes FC, Kartoglu UH, Metin GA, Widmer M. Quality of Oxytocin Available in Low and Middle-Income Countries: A Systematic Review of the Literature (Systematic Review on Quality of Oxytocin). BJOG. 2016 Dec;123(13):2076-86.

DOI: http://doi.org/10.1111/1471-0528.13998

6. Malm M, Madsen I, Kjellstrom J. Development and stability of a heat-stable formulation of carbetocin for the prevention of postpartum haemorrhage for use in low and middle-income countries. Journal of Peptide Science. 2018 June 24(6):e3082.

DOI: https://doi.org/10.1002/psc.3082

7. World Health Organisation. WHO study shows drug could save thousands of womens' lives. WHO 2018. 